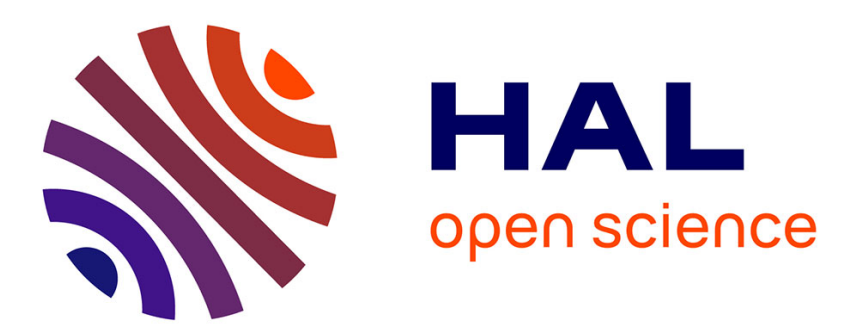

\title{
A field-pilot for passive bioremediation of As-rich acid mine drainage
}

L. Fernandez-Rojo, C. Casiot, E. Laroche, V. Tardy, O. Bruneel, S. Delpoux, A. Desoeuvre, G. Grapin, J. Savignac, J. Boisson, et al.

\section{> To cite this version:}

L. Fernandez-Rojo, C. Casiot, E. Laroche, V. Tardy, O. Bruneel, et al.. A field-pilot for passive bioremediation of As-rich acid mine drainage. Journal of Environmental Management, 2019, 232, pp.910-918. 10.1016/j.jenvman.2018.11.116 . hal-02075868

\section{HAL Id: hal-02075868 https://hal.science/hal-02075868}

Submitted on 21 Mar 2019

HAL is a multi-disciplinary open access archive for the deposit and dissemination of scientific research documents, whether they are published or not. The documents may come from teaching and research institutions in France or abroad, or from public or private research centers.
L'archive ouverte pluridisciplinaire HAL, est destinée au dépôt et à la diffusion de documents scientifiques de niveau recherche, publiés ou non, émanant des établissements d'enseignement et de recherche français ou étrangers, des laboratoires publics ou privés. 


\section{A field-pilot for passive bioremediation of As-rich acid mine}

\section{drainage}

Fernandez-Rojo L. ${ }^{\mathrm{a}, 1}$, Casiot C. ${ }^{\mathrm{a}^{*}}$, Laroche E. ${ }^{\mathrm{a}, \mathrm{b}}$, Tardy V. ${ }^{\mathrm{a}, 2}$, Bruneel O. ${ }^{\mathrm{a}}$, Delpoux S. ${ }^{\mathrm{a}}$, Desoeuvre A. ${ }^{a}$, Grapin G. ${ }^{c}$, Savignac J. ${ }^{\text {c }}$, Boisson J. ${ }^{\text {d }}$, Morin G. ${ }^{\text {e, }}$ Battaglia-Brunet F. ${ }^{\text {, }}$, Joulian C. ${ }^{\text {b }}$, Héry M. ${ }^{\mathrm{a}}$

a HydroSciences Montpellier, Univ. Montpellier, CNRS, IRD, 163 rue Auguste Broussonnet, 34090 Montpellier, France

${ }^{\mathrm{b}}$ French Geological Survey (BRGM), Geomicrobiology and environmental monitoring unit, 3, avenue Claude Guillemin, BP 36009, 45060 Orléans Cedex 2, France

c IRH Ingénieur Conseil, Anteagroup, 427 rue Lavoisier - CS 50155, 54714, Ludres Cedex, France

d IRH Ingénieur Conseil, Anteagroup, 197 avenue de Fronton, 31200, Toulouse, France

e Institut de Minéralogie, de Physique des Matériaux et de Cosmochimie (IMPMC), UMR 7590 CNRS-UPMC-IRD-MNHN, Sorbonne Universités, 4 place Jussieu, 75252 Paris cedex 05, France

*Author for correspondence: Corinne Casiot

Tel +33(0)4 67143356

Email: casiot@msem.univ-montp2.fr

Postal address: Université de Montpellier, Hydrosciences - CC57, 163 rue Auguste Broussonnet, 34090 Montpellier, France

Declarations of interest: none

\footnotetext{
${ }^{1}$ Present address: Institute of Environmental Assessment and Water Research (IDAEA), CSIC, Jordi Girona 18, 08034 Barcelona, Spain

${ }^{2}$ Present address: Irstea UR Milieux Aquatiques, Ecologie et Pollutions (UR MALY) - Irstea - 5 rue de la Doua BP 32108 F-69616 Villeurbanne Cedex, France
} 


\section{Abstract}

2 A field-pilot bioreactor exploiting microbial iron $(\mathrm{Fe})$ oxidation and subsequent arsenic 3 (As) and Fe co-precipitation was monitored during 6 months for the passive treatment 4 of As-rich acid mine drainage (AMD). It was implemented at the Carnoulès mining site 5 (southern France) where AMD contained 790-1315 mg L ${ }^{-1} \mathrm{Fe}(\mathrm{II})$ and $84-152 \mathrm{mg} \mathrm{L}^{-1}$

6 As, mainly as As(III) $(78-83 \%)$. The bioreactor consisted in five shallow trays of 1.5 $7 \mathrm{~m}^{2}$ in series, continuously fed with AMD by natural flow. We monitored the flow rate 8 and the water physico-chemistry including redox $\mathrm{Fe}$ and As speciation. Hydraulic 9 retention time (HRT) was calculated and the precipitates formed inside the bioreactor 10 were characterized (mineralogy, Fe and As content, As redox state). Since As(III) 11 oxidation improves As retention onto Fe minerals, bacteria with the capacity to oxidize $12 \mathrm{As}(\mathrm{III})$ were quantified through their marker gene aioA. Arsenic removal yields in the 13 pilot ranged between $3 \%$ to $97 \%$ (average rate $(1.8 \pm 0.8) \times 10^{-8} \mathrm{~mol} \mathrm{~L}^{-1} \mathrm{~s}^{-1}$ ), and were 14 positively correlated to HRT and inlet water dissolved oxygen concentration. Fe 15 removal yields did not exceed $11 \%$ (average rate $\left.(7 \pm 5) \times 10^{-8} \mathrm{~mol} \mathrm{~L}^{-1} \mathrm{~s}^{-1}\right)$. In the first 1632 days, the precipitate contained tooeleite, a rare arsenite ferric sulfate mineral. Then, 17 it evolved toward an amorphous ferric arsenate phase. The As/Fe molar ratio and As(V) 18 to total As proportion increased from 0.29 to 0.86 and from $\sim 20 \%$ to $99 \%$, 19 respectively. The number of bacterial aioA gene copies increased ten-fold during the 20 first 48 days and stabilized thereafter. These results and the monitoring of arsenic 21 speciation in the inlet and the outlet water, provide evidences that As(III) oxidized in 22 the pilot. The biotreatment system we designed proved to be suitable for high As DMA. 
23 The formation of sludge highly enriched into As(V) rather than As(III) is advantageous

24 in the perspective of long term storage.

26 Keywords: field bioreactor, passive treatment, As(III) oxidation, amorphous ferric 27 arsenate, tooeleite, arsenic removal rate

\section{1. Introduction}

29 Acid Mine Drainage (AMD) is one of the worst environmental hazards resulting from 30 the extraction of base metals from sulfide deposits. These leachates result from the 31 oxidation of metal sulfides (especially pyrite) in mine tailings. The process releases 32 sulfate, iron and a range of toxic metals and metalloids, often including arsenic. This 33 element can be present at high concentrations in AMD, up to $350 \mathrm{mg} \mathrm{L}^{-1}$ (Paikaray, 34 2015; Williams, 2001). Arsenic contamination may be attenuated to some extent by 35 natural processes which involve biotic and abiotic Fe(II) oxidation and the subsequent 36 precipitation of $\mathrm{Fe}(\mathrm{III})$-hydroxysulfates and $\mathrm{Fe}(\mathrm{III})$-oxyhydroxides, together with 37 arsenite (As(III)) and arsenate (As(V)) adsorption and/or co-precipitation (Cheng et al., 38 2009). The oxidation of arsenite into arsenate, which is efficiently mediated by bacteria 39 (Battaglia-Brunet et al., 2002; Bruneel et al., 2003) greatly improves As attenuation in 40 AMD. Indeed, the solubility of $\mathrm{As}(\mathrm{V})-\mathrm{Fe}(\mathrm{III})$-hydroxysulfates is lower than the 41 solubility of $\mathrm{As}(\mathrm{III})-\mathrm{Fe}(\mathrm{III})$-hydroxysulfates for a similar $\mathrm{As} / \mathrm{Fe}$ ratio in the solid 42 (Maillot et al., 2013). These natural processes can serve as a basis for the passive 43 treatment of As-rich AMD if they are exploited in suitable systems. Passive treatments, 44 that do not require neither power nor constant maintenance, are particularly adapted to 
45 remote locations. Numerous studies aimed to exploit microbial Fe(II) oxidation for the 46 removal of As from AMD in lab-scale bioreactors processing synthetic mine water (e.g. 47 Ahoranta et al., 2016; González-Contreras et al., 2012; Hedrich and Johnson, 2014). 48 Conversely, few trials have been attempted to exploit this process in field-pilot passive 49 bioreactors processing real AMD water (Elbaz-Poulichet et al., 2006; Macías et al., 50 2012; Whitehead et al., 2005) (Table 1).

51 In the present study, we investigated arsenic removal from an AMD containing extreme 52 As concentrations (up to $140 \mathrm{mg} \mathrm{L}^{-1}$ ) under the most mobile and toxic form, As(III) 53 (60-100\%, Casiot et al., 2003). The treatment consisted in a passive field-pilot 54 bioreactor exploiting iron oxidation by autochthonous bacterial communities, resulting 55 in the precipitation of $\mathrm{Fe}$ and As. The design of this reactor was derived from previous 56 laboratory experiments with a bench-scale channel bioreactor that provided up to $80 \%$ 57 As removal during the treatment of AMD water originating from the same site 58 (Fernandez-Rojo et al., 2017). The two key parameters of the bioreactor design were 1) 59 a low water height above the precipitate and 2) a good oxygenation of the feed water 60 (Fernandez-Rojo et al., 2017). The field-pilot bioreactor was continuously fed during 61 six months with AMD by natural flow. The AMD was the spring of the Reigous Creek 62 at the Carnoulès mine in southern France (OREME, 2018), whose biogeochemistry and 63 microbial communities involved in Fe and As attenuation have been previously studied 64 (Bruneel et al., 2006,2011; Casiot et al., 2003; Egal et al., 2010; Volant et al., 2014). 65 We monitored inlet and outlet water physico-chemistry and the composition of Fe-As 66 precipitate, including arsenic redox state in water and precipitate. To estimate potential 67 microbial contribution to arsenite oxidation, the gene encoding the large subunit of the 68 As(III) oxidase (aioA) was quantified. 


\section{Materials and methods}

\subsection{Field-scale passive bioreactor}

71 A flow pipe collected the AMD from its spring, located at the base of the Carnoulès 72 tailings dam, and transferred it to the bioreactor, located $115 \mathrm{~m}$ down the way (mean 73 slope of $5.9 \%)$. At the bioreactor inlet, a small feed tank $(52 \mathrm{~cm}$ length $\times 21 \mathrm{~cm}$ width

$74 \times 26 \mathrm{~cm}$ height) limited the flow rate entering the bioreactor by means of a V-notch weir and a siphon. The level of water in the V-notch weir tank was constant and it was adjustable by the height of the siphon. The overflow was redirected to the Reigous Creek through a flow pipe (Figure 1A). The inlet flow rate decreased over short time intervals ( one to two weeks) due to the inflow of sand particles into the AMD carrying pipes. Thus, cleaning these pipes was necessary after each sampling survey to restore

80 the flow rate. Besides, a decantation tank was inserted upstream from the AMD intake 81 after day 147 to limit the introduction of sand particles into the pipe.

82 Water circulation within the bioreactor was powered by natural flow. The bioreactor 83 consisted of five shallow trays stacked head to tail on a shelf (Figure 1). Each tray sized $841.5 \mathrm{~m}^{2}(1.5 \times 1 \mathrm{~m}), 0.11 \mathrm{~m}$ depth, and it was made of $10 \mathrm{~mm}$ thick polyethylene sheets. 85 Trays were divided into two compartments with a vertical separator leaving a $2 \mathrm{~cm}$ 86 space at the bottom. The main compartment $(1.2 \times 1 \mathrm{~m})$ was filled $3.5-4.5 \mathrm{~cm}$ in height 87 with $80 \mathrm{~kg}$ of sand from river Moselle (uniformity coefficient 5.73, diameter at $10 \%=$ $880.31 \mathrm{~mm}$, at $60 \%=1.78 \mathrm{~mm}$, at $85 \%=5.75 \mathrm{~mm}, \mathrm{CaCO}_{3}$ content $=0.19 \%$ ), in order to 89 provide a support for microbial attachment. The overflow fell over from the outlet end 90 of one tray to the inlet end of the next tray, through a polypropylene tube $(2 \mathrm{~cm} \mathrm{i.d.),}$ 
91 thus favoring the water oxygenation. Water passed through the different trays (T1, T2,

$92 \mathrm{~T} 3, \mathrm{~T} 4$ and T5) before being discharged to the AMD stream.

93

94 The bioreactor was monitored during 194 days, between June $10^{\text {th }} 2016$ and December

$9521^{\text {st }}$ 2016. Nine sampling surveys were made during the summer period (June, July),

96 one intermediate sampling in October, and four samplings during the autumn period

97 (November, December). At each sampling campaign, inlet and outlet waters were

98 collected. The following physico-chemical parameters were measured: $\mathrm{pH}$, dissolved

99 oxygen concentration (DO), temperature, redox potential (Eh) and electrical

100 conductivity (EC). We also determined dissolved concentrations of $\mathrm{Fe}(\mathrm{II})$, total $\mathrm{Fe}$,

$101 \mathrm{As}(\mathrm{III}), \mathrm{As}(\mathrm{V})$, and total As, after filtration $(0.22 \mu \mathrm{m})$ and preservation using procedures

102 described in Fernandez-Rojo et al. (2017). We measured the flow rate and the water

103 height in each tray in order to estimate the apparent hydraulic retention time (HRT). The

104 apparent HRT was the mean of the maximum and the minimum HRT. To determine the

105 maximum HRT, we assumed that water flowed through the sand pores and that there

106 was no precipitate accumulation. On the contrary, for minimum HRT determination, we

107 considered that the sand pores were clogged and that there was a precipitate layer above

108 the sand.The maximum and the minimum HRT, expressed in hours, were calculated

109 with the following Equation (1):

$$
\text { Maximum/Minimum HRT }=\frac{\sum_{i=1}^{n}\left(L_{i} * W_{i}\right) *\left(W H_{i}-P H_{i}\right)-\left(\frac{S W_{i}}{\delta}-\emptyset_{i}\right)}{Q}
$$


110 where " $\mathrm{L}_{\mathrm{i}}$ " and " $\mathrm{W}_{\mathrm{i}}$ " were the length and the width, respectively, in decimeters. "WH $\mathrm{H}_{\mathrm{i}}$ "

111 was the water height from the bottom of one tray measured in each sampling in

112 decimeters. " $\mathrm{PH}_{\mathrm{i}}$ " was the precipitate height above the sand layer of one tray expressed

113 in decimeters. "SW${ }_{\mathrm{i}}$ " was the sand weight in $\mathrm{kg}$, " $\delta$ " was the sand density in $\mathrm{kg} \mathrm{dm}{ }^{-3}$,

114 "ø" was the sand vacuum volume in $\mathrm{dm}^{3}$, and "Q" the water flow rate in $\mathrm{dm}^{3} \mathrm{~h}^{-1}$. " $\mathrm{n}$ "

115 corresponded to the number of trays (5) in the pilot. Details of these calculations are

116 given in the supporting information file.

\subsection{Analyses}

119

\subsubsection{Water samples}

120 All analytical procedures are detailed in Fernandez-Rojo et al. (2017). Briefly, the 121 concentrations of dissolved Fe(II) were determined using colorimetry at $510 \mathrm{~nm}$ after

122 complexation with 1,10-phenanthrolinium chloride. Total dissolved concentrations of

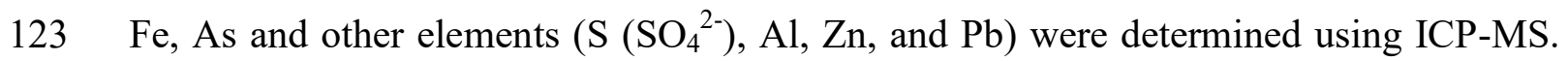

124 Arsenic redox speciation was determined using HPLC-ICP-MS.

125 The rates of $\mathrm{Fe}(\mathrm{II})$ oxidation, $\mathrm{Fe}$ - and As-removal (in $\mathrm{mol} \mathrm{L}^{-1} \mathrm{~s}^{-1}$ ) were calculated using 126 Equation (2):

$$
\text { Rate }=\frac{([X] \text { inlet }-[X] \text { outlet })}{H R T}
$$


127 where $[\mathrm{X}]$ was the concentration of dissolved $\mathrm{Fe}(\mathrm{II})$, total dissolved Fe, total dissolved

128 As, dissolved As(III) or dissolved As(V), respectively, in mol L ${ }^{-1}$ and HRT the apparent

129 hydraulic retention time in seconds.

130 Surface area is often a limitation in the design of passive treatments. To address this

131 issue and to compare with the literature data on water treatment processes (Table 1),

132 area-adjusted rates were calculated using Equation 3:

$$
\text { Area }- \text { adjusted rate }=\frac{([X] \text { inlet }-[X] \text { outlet }) * Q}{\text { Surface area }}
$$

133 where the concentration of total dissolved Fe or total dissolved As ([X]) were expressed 134 in $\mathrm{g} \mathrm{L}^{-1}$, the flow rate (Q) in $\mathrm{L} \mathrm{d}^{-1}$ and the surface area, in $\mathrm{m}^{2}$. Only the $7.5 \mathrm{~m}^{2}$ surface 135 above the sand layer was considered here because rapid clogging prevented water to 136 circulate through the sand layer.

\subsubsection{Solid samples}

138 When sampling the precipitate, the surface of each tray was divided in three zones

139 following the water flow path (Figure 1A): "A" refers to the $0.5 \mathrm{~m}^{2}$ surface area close to

140 the inlet of each tray, "B" represents the $0.5 \mathrm{~m}^{2}$ surface area in the middle section, and

141 "C" the $0.5 \mathrm{~m}^{2}$ surface area close to the outlet of each tray. The precipitate from trays T1

142 to T5 was collected with a sterilized spatula by scraping the solid surface. The 143 precipitate was transferred into Falcon Tubes $(50 \mathrm{~mL})$ and centrifuged for $10 \mathrm{~min}$ at $1444400 \times g$ (Sorwall ST40, Thermo Scientific). The supernatant was discarded and the 145 precipitate was homogenized. A portion of the sample $(\sim 0.3 \mathrm{~g})$ was dried in a vacuum 146 desiccator. Redox As determination was performed by HPLC-ICP-MS on a subsample 
147 (100 mg) after extraction with orthophosphoric acid (Resongles et al., 2016). No fine

148 particles remained after this procedure, enabling total As and Fe determination. Another

149 subsample was used for X-ray diffraction (XRD) and a third one for quantification of

150 aioA gene copy numbers. These procedures were detailed in Fernandez-Rojo et al.

151 (2017).

\section{$152 \quad$ 2.4. Statistics}

153 Friedman tests and Nemenyi post-hoc tests were performed with the XLSTAT 2018

154 software to compare the $\mathrm{As} / \mathrm{Fe}$ molar ratio, the $\mathrm{As}(\mathrm{V}) \%$ and the number of aioA 155 genes/ng of DNA of the biogenic precipitate between the sampling dates.

156 Principal Component Analysis (PCA) was performed on functional parameters of the

157 pilot (As and Fe removal yields and rates) using the vegan package under R software 158 (version 3.4.0) and provided an ordination of data in factorial maps based on the scores 159 of the first two principal components. HRT and water physico-chemistry (inlet and 160 outlet temperature and $\mathrm{DO}, \mathrm{pH}$, Eh, conductivity, Fe and As concentration, $\mathrm{Fe}$ (II) to 161 total Fe proportion, As(III) to total As proportion) were fit to PCA ordinations in order 162 to identify the correlations between these variables and the functional parameters of the 163 pilot.

\section{3. Results}

\subsection{Flow rate and hydraulic retention time}

166 The HRT calculation relies mainly on the flow rate. This parameter exhibited important 167 variations, from 6 to $130 \mathrm{~L} \mathrm{~h}^{-1}$ in relation with partial clogging of the pipe carrying the 
168 AMD to the bioreactor feed tank (Figure 2). The October survey (day 115) was

169 characterized by extremely low flow rate occurring after a two-month period without

170 flow pipe dredging. After day 147, a decantation tank was set up, resulting in a better

171 stabilization of the flow rate, between 30 and $49 \mathrm{~L} \mathrm{~h}^{-1}$. The HRT calculation also relies

172 on the water height measured from the bottom of the trays. This parameter varied

173 between 34 and $112 \mathrm{~mm}$. Indeed, the accumulation of precipitate within and over the

174 sand bed modified water discharge at the outlet of each tray, which subsequently

175 increased the water level within the tray. Consequently, the calculated apparent HRT

176 varied from $4 \mathrm{~h}$ to $\sim 50 \mathrm{~h}$ (Figure 2).

\section{$177 \quad 3.2$. Water physico-chemistry}

\subsubsection{Inlet water}

179 Inlet water $\mathrm{pH}, \mathrm{DO}$ and temperature exhibited notable variations over the monitoring

180 period (Figure 3). $\mathrm{pH}$ varied between 2.6 and 3.4 (Figure 3A). Dissolved oxygen

181 concentration was generally lower than $4 \mathrm{mg} \mathrm{L}^{-1}$ during the summer period (except on 182 day 45) and increased to $5.2 \pm 0.3 \mathrm{mg} \mathrm{L}^{-1}$ in the autumn period (Figure 3B). The water 183 temperature was higher during the summer period $\left(19 \pm 3{ }^{\circ} \mathrm{C}\right)$ than during the autumn 184 period $\left(11 \pm 1{ }^{\circ} \mathrm{C}\right)$ (Figure 3C). Eh averaged $539 \pm 30 \mathrm{mV}$ (Figure 3D). Total dissolved

185 Fe and As concentrations increased respectively from $962 \mathrm{mg} \mathrm{L}^{-1}$ to $1314 \mathrm{mg} \mathrm{L}^{-1}$ and 186 from 111 to $152 \mathrm{mg} \mathrm{L}^{-1}$ during the summer period and then decreased to $801 \pm 81 \mathrm{mg}$ $187 \mathrm{~L}^{-1}(\mathrm{Fe})$ and $92 \pm 10 \mathrm{mg} \mathrm{L}^{-1}$ (As) in the autumn period (Figure 3E-F). Both elements 188 were predominantly under the reduced redox state (more than $84 \% \mathrm{Fe}(\mathrm{II})$ and $78 \%$ 189 As(III) (Figure S1B-D)). Dissolved sulfate and metal cations (Al, Zn, Pb) 
190 concentrations in the inlet water averaged $2.8 \pm 0.5 \mathrm{~g} \mathrm{~L}^{-1}\left(\mathrm{SO}_{4}{ }^{2-}\right), 47 \pm 7 \mathrm{mg} \mathrm{L}^{-1}(\mathrm{Al}), 21$

$191 \pm 3 \mathrm{mg} \mathrm{L}^{-1}(\mathrm{Zn})$ and $1.5 \pm 0.3 \mathrm{mg} \mathrm{L}^{-1}(\mathrm{~Pb})$, respectively (Figure S1E-H).

192

\subsubsection{Outlet water}

193 There was a decrease of $\mathrm{pH}$ up to 0.4 unit in the outlet water compared to the inlet

194 (Figure 3A). Water temperature between inlet and outlet varied within $\pm 4^{\circ} \mathrm{C}$ during 195 summer period, while a decrease (up to $7.3^{\circ} \mathrm{C}$ ) was always observed during the autumn

196 period (Figure 3C). Dissolved oxygen most systematically increased, by $5 \mathrm{mg} \mathrm{L}^{-1}$ at 197 most, between inlet and outlet (except on day 45). Fe removal yield did not exceed 11 $198 \%$ (Figure 3E) and up to $20 \% \mathrm{Fe}$ (II) was oxidized (Figure S1B)). Arsenic removal yield 199 ranged from $3 \%$ to $97 \%$ (Figure 3F). The corresponding removal rates varied from 5.7 $200 \times 10^{-9}$ to $1.6 \times 10^{-7} \mathrm{~mol} \mathrm{~L}^{-1} \mathrm{~s}^{-1}$ for $\mathrm{Fe}$ (average rate $7 \pm 5 \times 10^{-8} \mathrm{~mol} \mathrm{~L}^{-1} \mathrm{~s}^{-1}$ ) and from 1 $201 \times 10^{-8}$ to $3.2 \times 10^{-8} \mathrm{~mol} \mathrm{~L}^{-1} \mathrm{~s}^{-1}$ for As (average rate $1.8 \pm 0.8 \times 10^{-8} \mathrm{~mol} \mathrm{~L}^{-1} \mathrm{~s}^{-1}$ ) (Figure

202 4). Reduced Fe(II) and As(III) species remained predominant upon oxidized species in 203 the outlet water (more than $85 \% \mathrm{Fe}(\mathrm{II})$ and $74 \% \mathrm{As}(\mathrm{III})$ ). The October data (day 115) 204 was an exception, with $98 \% \mathrm{As}(\mathrm{V})$ in the outlet water. Concentrations of dissolved $\mathrm{Al}$, $205 \mathrm{Zn}, \mathrm{S}\left(\mathrm{SO}_{4}{ }^{2-}\right)$ and $\mathrm{Pb}$ also decreased between inlet and outlet, by less than $12 \%$ for $\mathrm{Al}$, $206 \mathrm{Zn}, \mathrm{S}$ and up to $45 \%$ for $\mathrm{Pb}$ (Figure $\mathrm{S} 1 \mathrm{E}-\mathrm{H}$ ).

207 PCA illustrates the relationships between the functional parameters of the pilot (As and 208 Fe removal yields and rates) and the operating conditions including HRT and physico209 chemical variables (Figure 5). Days 115 to 194 (autumn period) were characterized by 210 the highest As removal yields, which were significantly correlated to HRT (p211 value $<0.001)$ and to inlet water DO concentration ( $p$-value $=0.006)$. Days 11, 27 and 
21232 were characterized by the highest Fe removal yields, which were negatively

213 correlated ( $\mathrm{p}$-value $=0.025)$ to the proportion of $\mathrm{Fe}(\mathrm{II})$ to total $\mathrm{Fe}$ in inlet water.

214 3.3. Biogenic precipitate: mineralogy, molar As/Fe ratios, As redox state and $215 \quad$ aio $A$ gene quantification

216 The precipitate recovered on the top of the sand layer contained quartz, mica, and 217 potassium feldspar all originating from the sand filter material (Figure 6). The Fe and 218 As content stabilized to $179 \pm 39 \mathrm{mg} \mathrm{Fe} \mathrm{g}^{-1}$ and $152 \pm 33 \mathrm{mg} \mathrm{As} \mathrm{g}^{-1}$ after 48 days (Table $219 \mathrm{~S} 1)$. Tooeleite, a ferric arsenite sulfate mineral $\left(\mathrm{Fe}_{6}\left(\mathrm{AsO}_{3}\right)_{4} \mathrm{SO}_{4}(\mathrm{OH})_{4} \cdot 4 \mathrm{H}_{2} \mathrm{O}\right)$ was the 220 only crystallized Fe-As phase identified. The XRD pattern also evidenced an 221 amorphous phase whose proportion increased at the expense of tooeleite, during the 222 monitoring period (Figure 6). The molar As/Fe ratio in the precipitate significantly 223 increased during the monitoring period from $\sim 0.3$ to $\sim 0.7$ in the three trays analyzed 224 (Figure 7A). The proportion of $\mathrm{As}(\mathrm{V})$ upon total As in the precipitate also increased 225 from $\sim 20 \%$ to $\sim 85 \%$ during the first 50 days, and then remained constant around 226 nearly $100 \%$ until the end of the monitoring period (Figure 7B). The color of the 227 precipitate changed throughout time, from orange to pale yellow (Figure S2).

228 The relative abundance of arsenite oxidizing bacteria was assessed through the 229 quantification of aioA genes. A ten-fold increase of the number of aioA genes was 230 observed in the precipitate between day 11 and day 48. From this date, the number of 231 aio $A$ genes remained relatively stable until the end of the monitoring period (Figure 232 7C). 


\section{Discussion}

\subsection{Arsenic and iron removal efficiency in the field-scale bioreactor}

235 The field pilot removed $3 \%$ to $97 \%$ of total dissolved As from the Carnoulès AMD, 236 while Fe removal yield did not exceed $11 \%$. The HRT had a significant influence on As

237 removal yields; the important variations of HRT during the monitoring period are both 238 due to flow rate fluctuations and to water level variations inside the trays. The average 239 As removal rate $\left((1.8 \pm 0.8) \times 10^{-8} \mathrm{~mol} \mathrm{~L}^{-1} \mathrm{~s}^{-1}\right)$ was close to our lab-scale experiments 240 rates $\left(2 \times 10^{-8}\right.$ to $\left.5 \times 10^{-8} \mathrm{~mol} \mathrm{~L}^{-1} \mathrm{~s}^{-1}\right)$ (Fernandez-Rojo et al., 2017). For comparison, in 241 a laboratory bioreactor exploiting microbial Fe(II) oxidation, Ahoranta et al. (2016) 242 obtained an As removal rate of $\sim 1.5 \times 10^{-10} \mathrm{~mol} \mathrm{~L}^{-1} \mathrm{~s}^{-1}$ during the treatment of a 243 synthetic AMD containing $10 \mathrm{mg} \mathrm{L}^{-1} \mathrm{As}(\mathrm{III})$ by adsorption onto biogenic jarosite at $\mathrm{pH}$ 244 3. Numerous factors, including water physico-chemistry, nature of precipitated solids, 245 and microbial communities might influence As removal rate in AMD (Asta et al., 2010, 246 2012). The Fe removal rate $\left((7 \pm 5) \times 10^{-8} \mathrm{~mol} \mathrm{~L}^{-1} \mathrm{~s}^{-1}\right)$ in the field pilot was within the 247 lower range of lab-scale experiments rates $\left(1.8\right.$ to $24 \times 10^{-8} \mathrm{~mol} \mathrm{~L}^{-1} \mathrm{~s}^{-1}$, Fernandez-Rojo 248 et al. (2017)). The field pilot oxidized less than $20 \% \mathrm{Fe}(\mathrm{II})$ whatever the HRT (Figure 249 S1-B), compared to nearly $100 \%$ in the lab-scale pilot (Fernandez-Rojo et al., 2017). 250 There was no link between Fe removal yield and HRT or inlet water DO (Figure 5). 251 Thus, the system appeared not very effective regarding Fe oxidation and removal. One 252 possible explanation is the large water height $(15-70 \mathrm{~mm})$ above the precipitate. We 253 demonstrated in our lab-scale bioreactor that large water height limits oxygen 254 availability (and then $\mathrm{Fe}$ (II) oxidation and subsequent Fe precipitation) at the 
255 water/precipitate interface, due to faster metabolic consumption, relative to the oxygen 256 diffusion (Fernandez-Rojo et al., 2017).

257 A few in situ devices exploiting microbial or abiotic Fe(II) oxidation have been 258 experienced so far for arsenic removal in AMD in a passive way (Table 1). They were 259 in the form of ponds (Elbaz-Poulichet et al., 2006), lagoons (Macías et al., 2012) or 260 wetlands (Hamilton et al., 1999; Whitehead et al., 2005). Some of them were preceded 261 by closed or open channels or drains filled with alkaline rocks (Caraballo et al., 2009; 262 Gusek et al., 1994; Rötting et al., 2008) in order to promote rapid abiotic Fe(II) 263 oxidation at near-neutral $\mathrm{pH}$ prior to As retention (Table 1). Most of these systems 264 achieved more than $80 \%$ removal for AMD containing low As concentrations $(<3$ $265 \mathrm{mg} \mathrm{L}^{-1}$ ). Area-adjusted arsenic removal rates obtained in the present study were higher $266\left(3-12 \mathrm{~g} \mathrm{~m}^{-2} \mathrm{~d}^{-1}\right)$ than those described in previous studies, in relation with higher 267 dissolved arsenic content. The high As concentration of the Carnoulès AMD is 268 particularly challenging. In a previous field-pilot experiment in Carnoulès, only 13-20

$269 \%$ As removal was achieved (Elbaz-Poulichet et al., 2006). The present bioreactor 270 showed a substantial improvement of As removal yield.

\subsection{As-bearing phases formed in the pilot}

272 Tooeleite and an amorphous-Fe-As phase were identified in the biogenic precipitate of 273 the field-pilot. These mineral phases have been observed for years in the upstream 274 section of Reigous Creek, in fresh and dry sediments, and in laminated concretions 275 (Morin et al., 2003; Egal et al., 2010). These solid phases were favored upon the most 276 widespread As-schwertmannite due to the As/Fe ratio exceeding 0.3 in the precipitate.

277 Indeed, an As/Fe ratio higher than 0.15 was shown to disrupt the crystallization of 
278 As(V)-schwertmannite (Carlson et al., 2002). In the field-pilot, tooeleite was replaced 279 over time by an amorphous phase subsequently to As(V) enrichment in the precipitate 280 (Figure 6; Table S1), consistently with the study of Liu et al. (2015). These authors

281 found that the crystallinity of tooeleite decreased with increasing $\mathrm{As}(\mathrm{V}) / \mathrm{As}(\mathrm{III})$ ratio 282 and no more tooeleite was detected on the XRD spectrum when the $\mathrm{As}(\mathrm{V}) / \mathrm{As}(\mathrm{III})$ ratio 283 exceeded 0.4 (Liu et al., 2015). The latter conditions occurred after day 19 in the present 284 experiment, with $\mathrm{As}(\mathrm{V}) / \mathrm{As}(\mathrm{III})$ ratio in the precipitate increasing beyond 0.7 . This is 285 consistent with the formation of an amorphous ferric arsenate phase. Future work 286 should examine whether the characteristics of As-bearing phases (As content, As/Fe 287 ratio and mineralogy) and their evolution over the long-term constitute limiting factors 288 in the achievement of the lowest As concentration in the treated water.

\subsection{Arsenic oxidation}

$290 \mathrm{As}(\mathrm{III})$ was predominant $(>78 \%)$ over $\mathrm{As}(\mathrm{V})$ in the feed water and both $\mathrm{As}(\mathrm{III})$ and $291 \mathrm{As}(\mathrm{V})$ species were removed from the dissolved phase in similar proportion in the 292 bioreactor (Figure S1C-D). Conversely, As(V) was predominant (> $50 \%$ ) over As(III) 293 in the precipitate after 20 days functioning and reached nearly one hundred percent in 294 trays T1-C, T2-C and T5-C after 170 days (Figure 7B; Table S1). Thus, As(III) 295 appeared to be oxidized within the field pilot. Both biotic and abiotic As(III) oxidation 296 may be involved. Abiotic As(III) oxidation may occur in presence of dissolved Fe(III) 297 (Asta et al., 2012; Emett and Khoe, 2001) or at the surface of Fe(III) minerals (Bhandari 298 et al., 2011; 2012; Paikaray et al., 2014; Pozdnyakov et al., 2016; Sun and Doner, 1998) 299 in acidic environments in presence of light. However, batch experiments conducted with 300 AMD waters from Carnoulès showed that the photochemical oxidation was negligible 
301 compared to the biological oxidation (Egal et al., 2009). Similar results were obtained

302 by other authors in an acid hydrothermal discharge (Leiva et al., 2014).

303 Furthermore, the temporal increase of the As-oxidation genetic potential (expressed as 304 the number of copies of aioA genes/ng of DNA) during the first 50 days (Figure 6C)

305 strongly suggests the establishment of As(III)-oxidizing bacteria in the biogenic 306 precipitate. The As(III)-oxidizing Thiomonas spp. have proved to be active members of

307 the bacterial community in the Reigous Creek (Bruneel et al., 2011). They are the only 308 arsenite oxidizers described so far in Carnoulès where they express in situ their arsenite 309 oxidation activity catalyzed by the AioA enzyme (Hovasse et al., 2016). We can 310 therefore hypothesize that arsenite oxidation occurring in the bioreactor is mainly 311 biological.

\section{5. Conclusion and perspectives}

313 The present field system provided As removal at a similar rate than the lab-scale pilot.

314 However, the water circulation in the system must be improved to stabilize the HRT in

315 future work. Fe oxidation and precipitation yield appeared to be limited by the large 316 water height above the precipitate. Nevertheless, the low amount of iron precipitated 317 (maximum $11 \%$ ), compared to other systems where the AMD is neutralized, enables 318 the production of low amounts of sludge, highly concentrated in arsenic (up to $20 \%$ dry 319 weight), thus limiting the cost of As-rich sludge disposal in engineered hazardous 320 wastes landfill facilities. The nature of the As-bearing phases produced, mainly 321 amorphous ferric arsenate, is advantageous in the perspective of long-term storage of 322 these treatment sludges. This solid phase has a high As load and a low solubility 323 compared to As(III)-Fe(III) phases (Langmuir et al., 2006; Virčíková et al., 1995; 
324 Maillot et al., 2013). However, the influence of storage conditions on sludge stability 325 needs to be fully evaluated.

326 Future efforts should focus on As removal rate improvement. For this, higher 327 oxygenation should be tested, together with the introduction in the trays of a physical 328 support with high pore volume, such as pozzolana, to prevent fast clogging and to 329 maximize surface area of Fe-and As-oxidizing biofilm per unit of water volume 330 (Battaglia-Brunet et al., 2006). In the perspective of upscaling of the treatment unit, 331 long-term monitoring would be necessary to explore possible seasonal variation of the 332 removal yields and As redox state in the precipitate. Long-term monitoring would also 333 provide information on the frequency of sludge removal from the system. Furthermore,

334 the spatio-temporal dynamic of bacteria involved in Fe(II) and As(III) oxidation such as

335 Thiomonas spp. in the present field-scale pilot deserves further research.

336 This treatment could be implemented as one step targeting arsenic in a multi-step AMD

337 treatment. Indeed, iron, sulfate and metal cations $(\mathrm{Al}, \mathrm{Zn}, \mathrm{Pb})$ are only partially removed 338 by this treatment and outlet $\mathrm{pH}$ remains acid $(\mathrm{pH} 3)$. A sulfate reduction bioreactor 339 could be implemented to raise the $\mathrm{pH}$ and selectively recover zinc in the form of sulfide 340 (Chen et al., 2016; Hedrich and Johnson, 2014; Le Pape et al., 2017). A finish treatment 341 such as Dispersed alkaline substrate (DAS) and decantation ponds might be used to 342 further raise the $\mathrm{pH}$ and remove remaining $\mathrm{Fe}, \mathrm{Al}$, and other metal cations, before 343 discharge into natural water bodies (Caraballo et al., 2011, 2009; Rötting et al., 2008).

\section{Acknowledgements}

345 The authors thank the IngECOST-DMA project (ANR-13-ECOT-0009), the OSU 346 OREME (SO POLLUMINE Observatory, funded since 2009) and the Ecole Doctorale 
347 GAIA (PhD fellowship of Lidia Fernandez-Rojo, 2014-2017) for the financial support.

348 We thank Remi Freydier and Léa Causse for ICP-MS analysis on the AETE-ISO 349 platform (OSU OREME, University of Montpellier). We thank Pierre Marchand for his 350 assistance in field sampling campaigns. We thank Simone Toller, from the University of 351 Pisa, for his valuable involvement during the setup of the bioreactor. We thank Qiuwei $352 \mathrm{Li}$, from the Université Pierre et Marie Curie, for her contribution in XRD 353 measurements during her internship at Institut de minéralogie, de physique des 354 matériaux et de cosmochimie (IMPMC). 
Ahoranta, S.H., Kokko, M.E., Papirio, S., Özkaya, B., Puhakka, J.A., 2016. Arsenic removal from acidic solutions with biogenic ferric precipitates. J. Hazard. Mater. 306, 124-132. doi:10.1016/j.jhazmat.2015.12.012

Asta, M.P., Ayora, C., Acero, P., Cama, J., 2010. Field rates for natural attenuation of arsenic in Tinto Santa Rosa acid mine drainage (SW Spain). J. Hazard. Mater. 177, 1102-1111. doi:10.1016/j.jhazmat.2010.01.034

Asta, M.P., Kirk Nordstrom, D., Blaine McCleskey, R., 2012. Simultaneous oxidation of arsenic and antimony at low and circumneutral $\mathrm{pH}$, with and without microbial $\begin{array}{llll}\text { catalysis. } & \text { Appl. } & \text { Geochem. 281-291. }\end{array}$ doi:http://dx.doi.org/10.1016/j.apgeochem.2011.09.002

Battaglia-Brunet, F., Dictor, M.-C., Garrido, F., Crouzet, C., Morin, D., Dekeyser, K., Clarens, M., Baranger, P., 2002. An arsenic(III)-oxidizing bacterial population: selection, characterization, and performance in reactors. J. Appl. Microbiol. 93, 656-667. doi:10.1046/j.1365-2672.2002.01726.x

Battaglia-Brunet, F., Itard, Y., Garrido, F., Delorme, F., Crouzet, C., Greffie, C., Joulian, C., 2006. A simple biogeochemical process removing arsenic from a mine drainage water. Geomicrobiol. J. 23, 201-211. doi:10.1080/01490450600724282

Bhandari, N., Reeder, R.J., Strongin, D.R., 2011. Photoinduced oxidation of arsenite to arsenate on ferrihydrite. Environ. Sci. Technol. 45, 2783-2789. doi:10.1021/es103793y

Bhandari, N., Reeder, R.J., Strongin, D.R., 2012. Photoinduced oxidation of arsenite to arsenate on goehite. Environ. Sci. Technol. 46, 8044-8051. doi:/10.1021/es300988p

Bruneel, O., Personné, J.C., Casiot, C., Leblanc, M., Elbaz-Poulichet, F., Mahler, B.J., Le Flèche, A., Grimont, P.A.D., 2003. Mediation of arsenic oxidation by Thiomonas sp. in acid-mine drainage (Carnoulès, France). J. Appl. Microbiol. 95, 492-499. doi : 10.1046/j.1365-2672.2003.02004.x

Bruneel, O., Duran, R., Casiot, C., Elbaz-Poulichet, F., Personné, J.C., 2006. Diversity of microorganisms in Fe-As-rich acid mine drainage waters of Carnoulès, France. Appl. Environ. Microbiol. 72, 551-556. doi:10.1128/AEM.72.1.551-556.2006

Bruneel, O., Volant, A., Gallien, S., Chaumande, B., Casiot, C., Carapito, C., Bardil, A., Morin, G., Brown Jr., G.E., Personné, J.C., Le Paslier, D., Schaeffer, C., Van Dorsselaer, A., Bertin, P.N., Elbaz-Poulichet, F., Arsène-Ploetze, F., 2011. Characterization of the active bacterial community involved in natural attenuation processes in arsenic-rich creek sediments. Microb. Ecol. 61, 793-810. doi:10.1007/s00248-011-9808-9 
405

406

407

408

409

410

411

412

413

414

415

416

417

418

419

420

421

422

423

424

425

426

427

428

429

430

431

432

Caraballo, M.A., Rötting, T.S., Macías, F., Nieto, J.M., Ayora, C., 2009. Field multistep limestone and $\mathrm{MgO}$ passive system to treat acid mine drainage with high metal concentrations. Appl. Geochem. 24, 2301-2311. doi:10.1016/j.apgeochem.2009.09.007

Caraballo, M.A., Macías, F., Rötting, T.S., Nieto, J.M., Ayora, C., 2011. Long term remediation of highly polluted acid mine drainage: A sustainable approach to restore the environmental quality of the Odiel river basin. Environ. Pollut. 159, 3613-3619. doi:10.1016/j.envpol.2011.08.003

Carlson, L., Bigham, J.M., Schwertmann, U., Kyek, A., Wagner, F., 2002. Scavenging of As from acid mine drainage by schwertmannite and ferrihydrite: a comparison with synthetic analogues. Environ. Sci. Technol. 36, 17121719.doi:10.1021/es0110271

Casiot, C., Morin, G., Juillot, F., Bruneel, O., Personné, J.-C., Leblanc, M., Duquesne, K., Bonnefoy, V., Elbaz-Poulichet, F., 2003. Bacterial immobilization and oxidation of arsenic in acid mine drainage (Carnoulès creek, France). Water Res. 37, 2929-2936. doi:http://dx.doi.org/10.1016/S0043-1354(03)00080-0

Chen, C.-J., Jiang, W.-T., 2012. Influence of waterfall aeration and seasonal temperature variation on the iron and arsenic attenuation rates in an acid mine drainage system. Appl. Geochem. 27, 1966-1978. doi:http://dx.doi.org/10.1016/j.apgeochem.2012.06.003

Chen, L.-X., Huang, L.-N., Méndez-García, C., Kuang, J.-L., Hua, Z.-S., Liu, J., Shu, W.-S., 2016. Microbial communities, processes and functions in acid mine drainage ecosystems. Curr. Opin. Biotechnol. 38, 150-158. doi:10.1016/j.copbio.2016.01.013

Cheng, H., Hu, Y., Luo, J., Xu, B., Zhao, J., 2009. Geochemical processes controlling fate and transport of arsenic in acid mine drainage (AMD) and natural systems. $J$ Hazard Mater. 165, 13-26. doi: 10.1016/j.jhazmat.2008.10.070.

Egal, M., Casiot, C., Morin, G., Parmentier, M., Bruneel, O., Lebrun, S., ElbazPoulichet, F., 2009. Kinetic control on the formation of tooeleite, schwertmannite and jarosite by Acidithiobacillus ferrooxidans strains in an As(III)-rich acid mine water. Chem. Geol. 265, 432-441. doi:10.1016/j.chemgeo.2009.05.008

Egal, M., Casiot, C., Morin, G., Elbaz-Poulichet, F., Cordier, M.-A., Bruneel, O., 2010. An updated insight into the natural attenuation of As concentrations in Reigous Creek (southern France). Appl. Geochem. 25, 1949-1957. doi:http://dx.doi.org/10.1016/j.apgeochem.2010.10.012

Elbaz-Poulichet, F., Bruneel, O., Casiot, C., 2006. The Carnoulès mine. Generation of As-rich acid mine drainage, natural attenuation processes and solutions for passive in-situ remediation, in: Difpolmine (Diffuse Pollution From Mining Activities).

Emett, M.T., Khoe, G.H., 2001. Photochemical oxidation of arsenic by oxygen and iron in acidic solutions. Water Res. 35, 649-656. doi:http://dx.doi.org/10.1016/S0043- 
434

Fernandez-Rojo, L., Héry, M., Le Pape, P., Braungardt, C., Desoeuvre, A., Torres, E., Tardy, V., Resongles, E., Laroche, E., Delpoux, S., Joulian, C., Battaglia-Brunet, F., Boisson, J., Grapin, G., Morin, G., Casiot, C., 2017. Biological attenuation of arsenic and iron in a continuous flow bioreactor treating acid mine drainage (AMD). Water Res. 123, 594-606. doi:10.1016/j.watres.2017.06.059

González-Contreras, P., Weijma, J., Buisman, C.J.N., 2012. Continuous bioscorodite crystallization in CSTRs for arsenic removal and disposal. Water Res. 46, 58835892. doi:10.1016/j.watres.2012.07.055

Gusek, J.J., Gormley, J.T., Scheetz, J.W., 1994. Design and construction aspects of pilot-scale passive treatment systems for acid rock drainage at metal mines. Hydrometallurgy 777-793. doi:10.1007/978-94-011-1214-7

Hamilton, Q.U.I., Lamb, H.M., Hallett, C., Proctor, J. a., 1999. Passive treatment systems for the remediation of acid mine drainage at Wheal Jane, Cornwall. Water Environ. J. 13, 93-103. doi:10.1111/j.1747-6593.1999.tb01014.x

Hedrich, S., Johnson, D.B., 2014. Remediation and selective recovery of metals from acidic mine waters using novel modular bioreactors. Environ. Sci. Technol. 48, 12206-12212. doi:10.1021/es5030367

Hovasse, A., Bruneel, O., Casiot, C., Desoeuvre, A., Farasin, J., Hery, M., Van Dorsselaer, A., Carapito, C., Arsène-Ploetze, F., 2016. Spatio-temporal detection of the Thiomonas population and the Thiomonas arsenite oxidase involved in natural arsenite attenuation processes in the Carnoulès acid mine drainage. Front. Cell Dev. Biol. 4, 1-14. doi:10.3389/fcell.2016.00003

Langmuir, D., Mahoney, J., Rowson, J., 2006. Solubility products of amorphous ferric arsenate and crystalline scorodite $\left(\mathrm{FeAsO}_{4} \cdot 2 \mathrm{H}_{2} \mathrm{O}\right)$ and their application to arsenic behavior in buried mine tailings. Geochim. Cosmochim. Acta 70, 2942-2956. doi:10.1016/j.gca.2006.03.006

Leiva, E.D., Rámila, C. d P., Vargas, I.T., Escauriaza, C.R., Bonilla, C.A., Pizarro, G.E., Regan, J.M., Pasten, P.A., 2014. Natural attenuation process via microbial oxidation of arsenic in a high Andean watershed. Sci. Total Environ. 466-467, 490-502. doi:10.1016/j.scitotenv.2013.07.009

Le Pape, P., Battaglia-Brunet, F., Parmentier, M., Joulian, C., Gassaud, C., FernandezRojo, L., Guigner, J.-M., Ikogou, M., Stetten, L., Olivi, L., Casiot, C., Morin, G., 2017. Complete removal of arsenic and zinc from a heavily contaminated acid mine drainage via an indigenous SRB consortium. J. Hazard. Mater. 321, 764-772. doi:10.1016/j.jhazmat.2016.09.060

Liu, J., Deng, S., Zhao, F., Cheng, H., Frost, R.L., 2015. Spectroscopic characterization and solubility investigation on the effects of $\mathrm{As}(\mathrm{V})$ on mineral structure tooeleite $\left(\mathrm{Fe}_{6}\left(\mathrm{AsO}_{3}\right)_{4} \mathrm{SO}_{4}(\mathrm{OH})_{4} \cdot \mathrm{H}_{2} \mathrm{O}\right)$. Spectrochim. Acta A Mol. Biomol. Spectrosc. 134, 428-433. doi:10.1016/j.saa.2014.06.111 
490

491

492

493

Macías, F., Caraballo, M.A., Nieto, J.M., Rötting, T.S., Ayora, C., 2012. Natural pretreatment and passive remediation of highly polluted acid mine drainage. J. Environ. Manage. 104, 93-100. doi:http://dx.doi.org/10.1016/j.jenvman.2012.03.027

Maillot, F., Morin, G., Juillot, F., Bruneel, O., Casiot, C., Ona-Nguema, G., Wang, Y., Lebrun, S., Aubry, E., Vlaic, G., Brown Jr., G.E., 2013. Structure and reactivity of $\mathrm{As}(\mathrm{III})$ - and As(V)-rich schwertmannites and amorphous ferric arsenate sulfate from the Carnoulès acid mine drainage, France: comparison with biotic and abiotic model compounds and implications for As remediation. Geochim. Cosmochim. Acta 104, 310-329. doi:10.1016/j.gca.2012.11.016.

Morin, G., Juillot, F., Casiot, C., Bruneel, O., Personné, J.-C., Elbaz-Poulichet, F., Leblanc, M., Ildefonse, P., Calas, G., 2003. Bacterial formation of tooeleite and mixed arsenic(III) or arsenic(V)-iron(III) gels in the Carnoulès acid mine drainage, France. A XANES, XRD, and SEM study. Environ. Sci. Technol. 37, 1705-1712. doi:10.1021/es025688p

OREME, observatoire de l'ancien site minier de Carnoulès (2018).

Paikaray, S., Essilfie-Dughan, J., Göttlicher, J., Pollok, K., Peiffer, S., 2014. Redox stability of As(III) on schwertmannite surfaces. J. Hazard. Mater. 265, 208-216. doi:10.1016/j.jhazmat.2013.11.068

Paikaray, S., 2015. Arsenic geochemistry of acid mine drainage. Mine Water Environ. 34, 181-196. doi:10.1007/s10230-014-0286-4

Pozdnyakov, I.P., Ding, W., Xu, J., Chen, L., Wu, F., Grivin, V.P., Plyusnin, V.F., 2016. Photochemical transformation of an iron(III)-arsenite complex in acidic aqueous solution. Photochem. Photobiol. Sci. 15, 431-439. doi:10.1039/c5pp00240k

Resongles, E., Le Pape, P., Fernandez-Rojo, L., Morin, G., Brest, J., Guo, S., Casiot, C., 2016. Routine determination of inorganic arsenic speciation in precipitates from acid mine drainage using orthophosphoric acid extraction followed by HPLC-ICPMS. Anal. Methods 8, 7420-7426. doi:10.1039/c6ay02084d

Rötting, T.S., Caraballo, M.A., Serrano, J.A., Ayora, C., Carrera, J., 2008. Field application of calcite Dispersed Alkaline Substrate (calcite-DAS) for passive treatment of acid mine drainage with high Al and metal concentrations. Appl. Geochem. 23, 1660-1674. doi:10.1016/j.apgeochem.2008.02.023

Sun, X., Doner, H.E., 1998. Adsorption and oxidation of arsenite on goethite. Soil Sci. 163, 278-287. doi:10.1097/00010694-199804000-00003

Virčíková, E., Molnár, L., Lech, P., Reitznerová, E., 1995. Solubilities of amorphous Fe-As precipitates. Hydrometallurgy 38, 111-123. doi:http://dx.doi.org/10.1016/0304-386X(94)00072-B 
512 Volant, A., Bruneel, O., Desoeuvre, A., Héry, M., Casiot, C., Bru, N., Delpoux, S., 513 Fahy, A., Javerliat, F., Bouchez, O., Duran, R., Bertin, P.N., Elbaz-Poulichet, F., 514 Lauga, B., 2014. Diversity and spatiotemporal dynamics of bacterial communities: 515 physicochemical and other drivers along an acid mine drainage. FEMS Microbiol. 516 Ecol. 90, 247-263. doi:10.1111/1574-6941.12394

517 Whitehead, P.G., Hall, G., Neal, C., Prior, H., 2005. Chemical behaviour of the Wheal 518 Jane bioremediation system. Sci. Total Environ. 338, 41-51. 519 doi:10.1016/j.scitotenv.2004.09.004

520 Williams, M., 2001. Arsenic in mine waters: an international study. Environ. Geol. 40, $521 \quad$ 267-278. doi:10.1007/s002540000162 
A

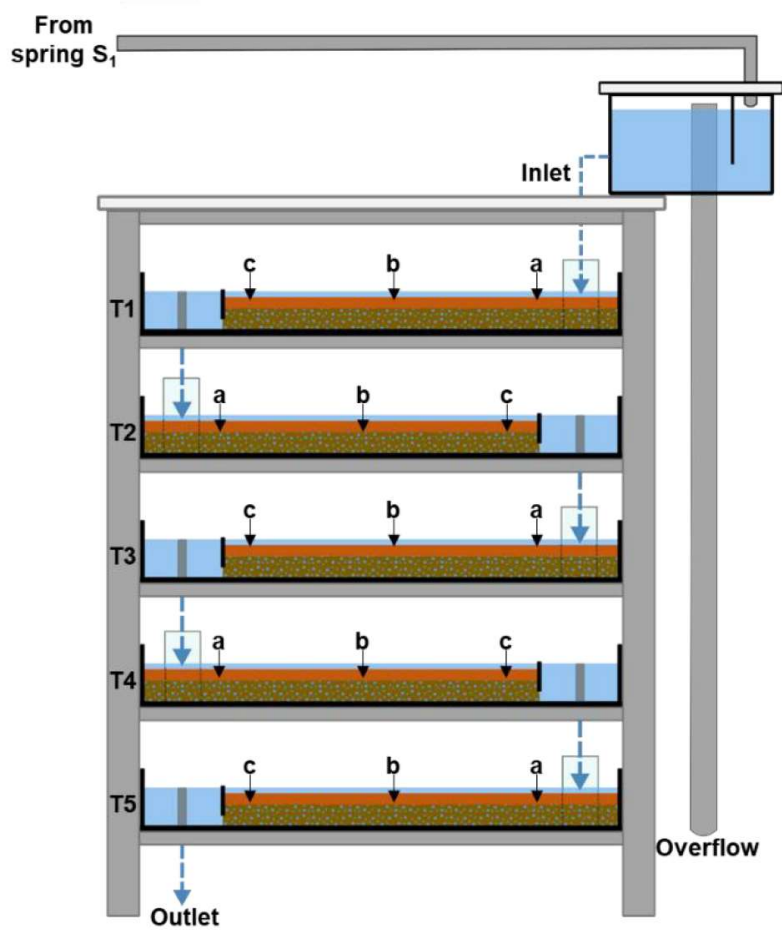

NOT TO SCALE
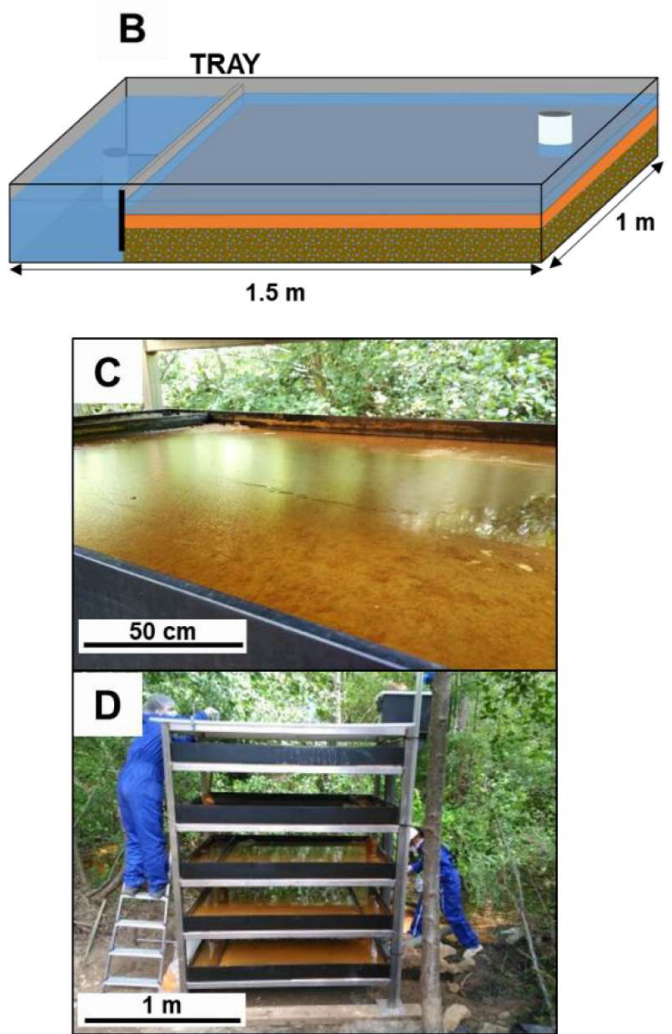

Figure 1. Schematic representation of the field bioreactor with the five trays $(\mathrm{T}=$ tray) (A) and detail of each tray (B). Pictures of one of the trays showing the orange biogenic precipitate below the thin water layer $(\mathrm{C})$, and of the whole field bioreactor (D) from June 2016. Letters $\mathrm{a}, \mathrm{b}$ and $\mathrm{c}$ in (A) indicate the biogenic precipitates sampling locations. 


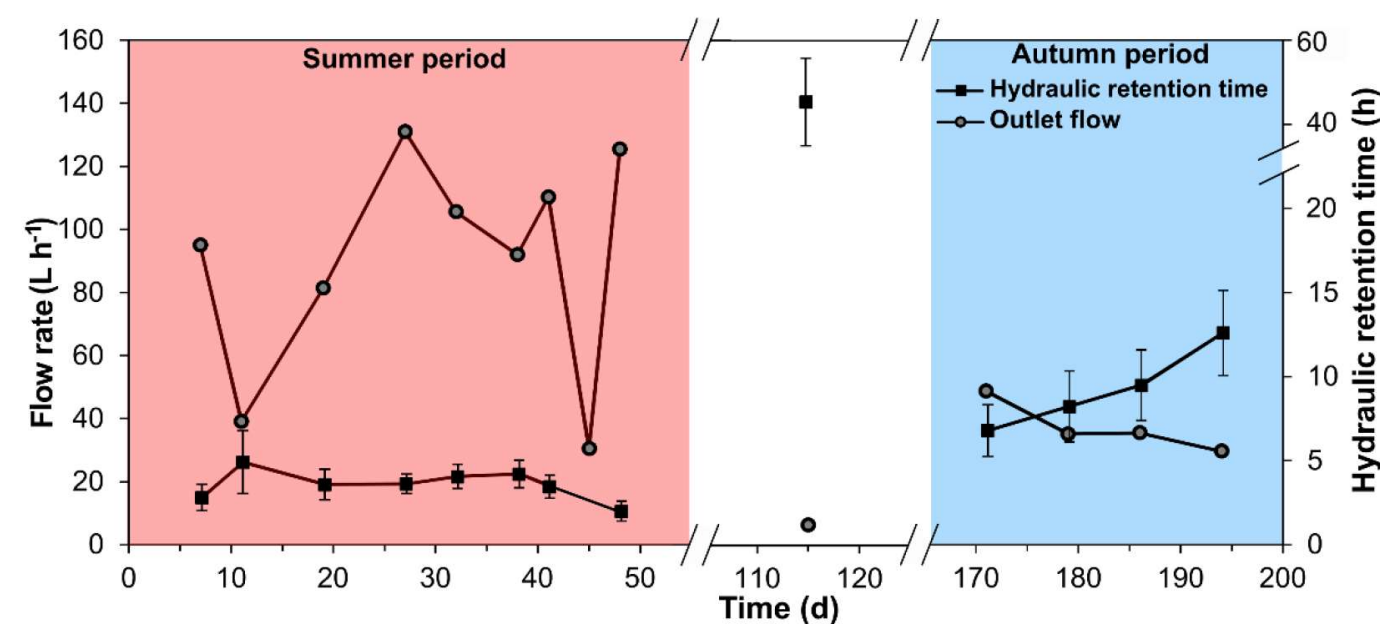

Figure 2. Variation of the flow rate during the monitoring period and estimation of the HRT. 

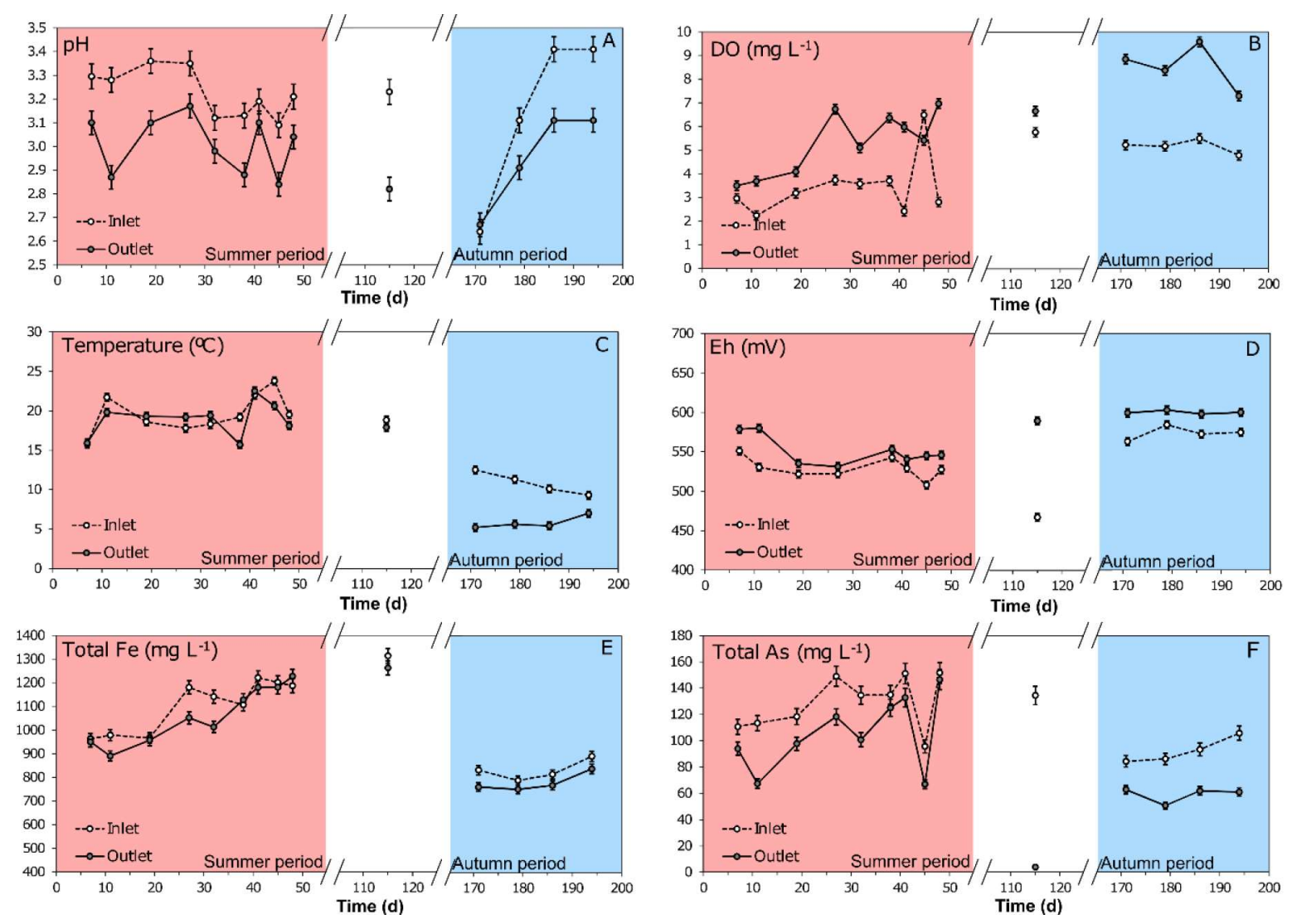

Figure 3. Monitoring of inlet and outlet water $\mathrm{pH}(\mathrm{A})$, dissolved oxygen concentration (B), temperature (C), redox potential (D), total dissolved Fe concentration (E), and total dissolved As concentration $(F)$ in the field bioreactor. 

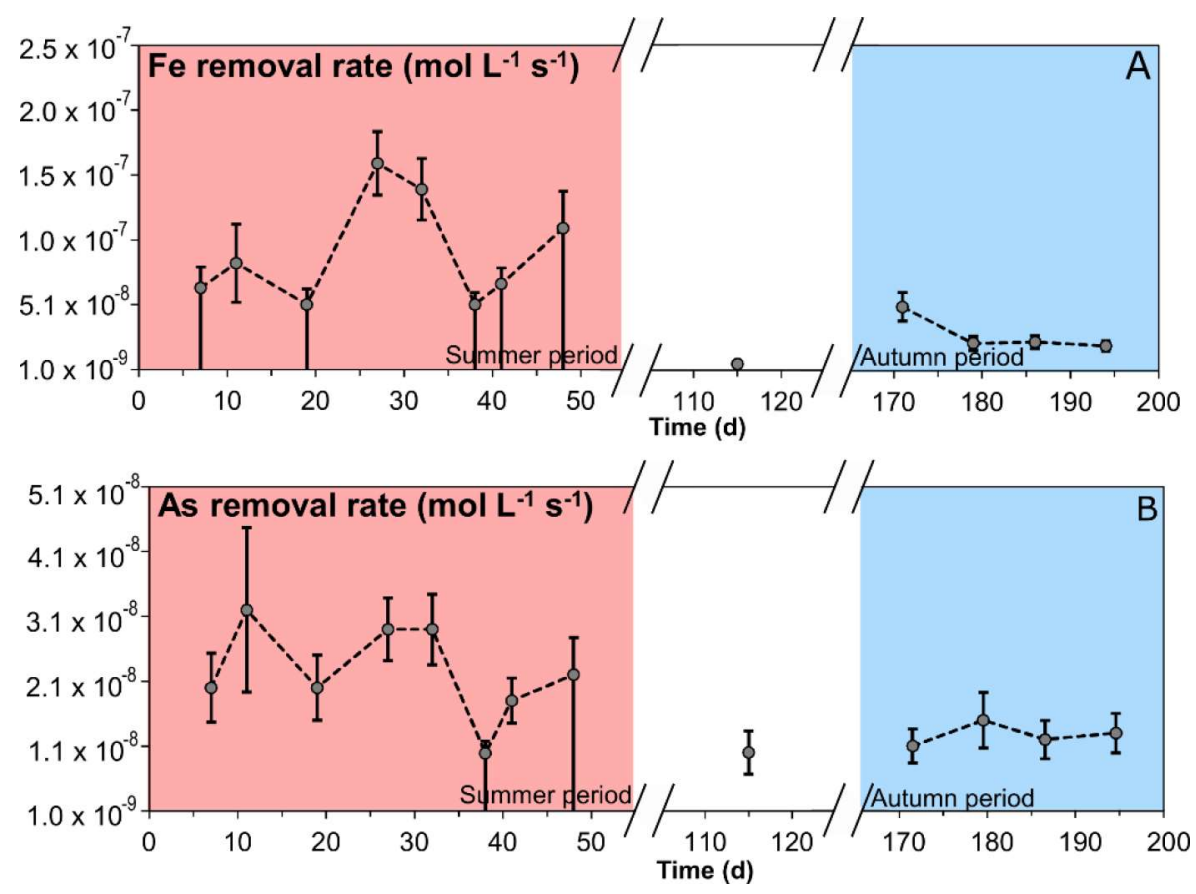

Figure 4. Monitoring of the $\mathrm{Fe}(\mathrm{A})$ and As removal rates $(\mathrm{B})$ in the field bioreactor. Rate values represented by a high negative $\mathrm{SD}$ correspond to maximum removal rates estimated from the analytical detection limit (no significant total $\mathrm{Fe}$ or total As concentration decrease between inlet and outlet). 


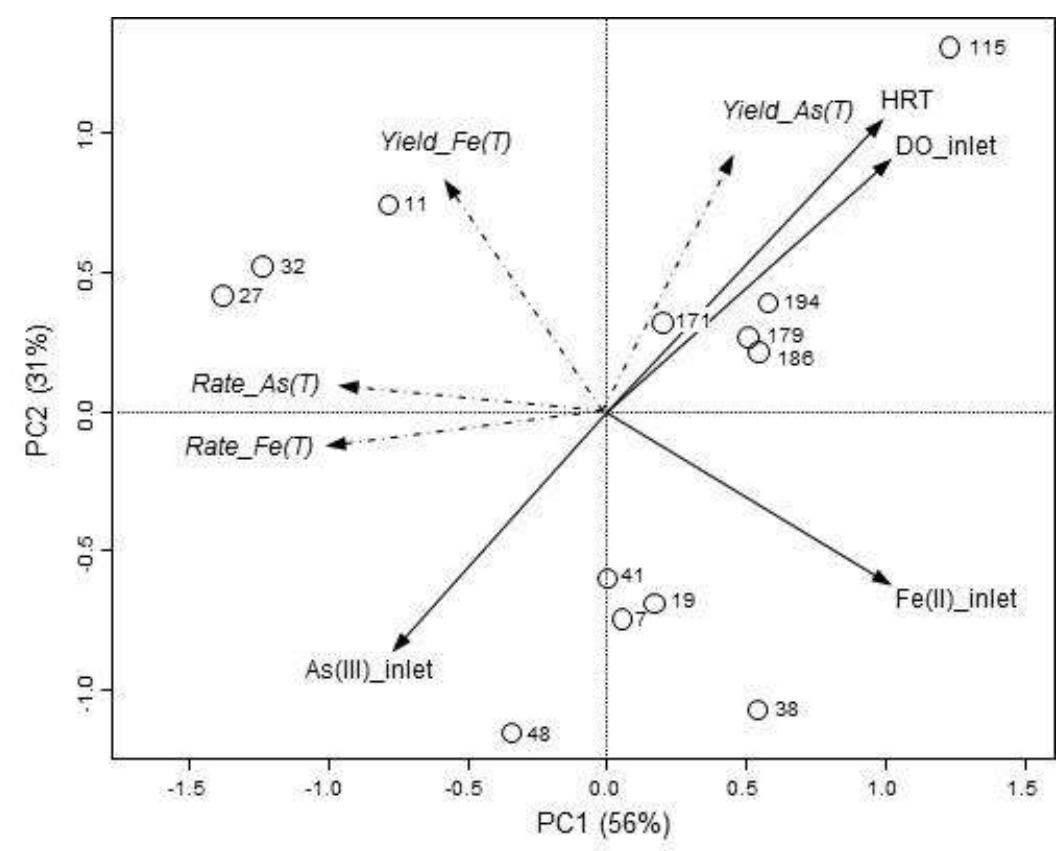

Figure 5. Principal Component Analysis $(\mathrm{PC} 1 \times \mathrm{PC} 2)$ based on functional parameters (total As and total Fe removal yields and rates) of the bioreactor across time. Circles with numbers represent the sampling days after the bioreactor setup. Vectors in the biplot overlay were constructed from a data frame containing HRT and water physicochemistry parameters (inlet and outlet temperature, DO, pH, Eh, conductivity, Fe and As concentrations and proportions of $\mathrm{Fe}$ (II) to total $\mathrm{Fe}$ and $\mathrm{As}$ (III) to total As). Only correlations with p-values $\leq 0.05$ were included. The angle and length of the vector indicate the direction and strength of the variable. 


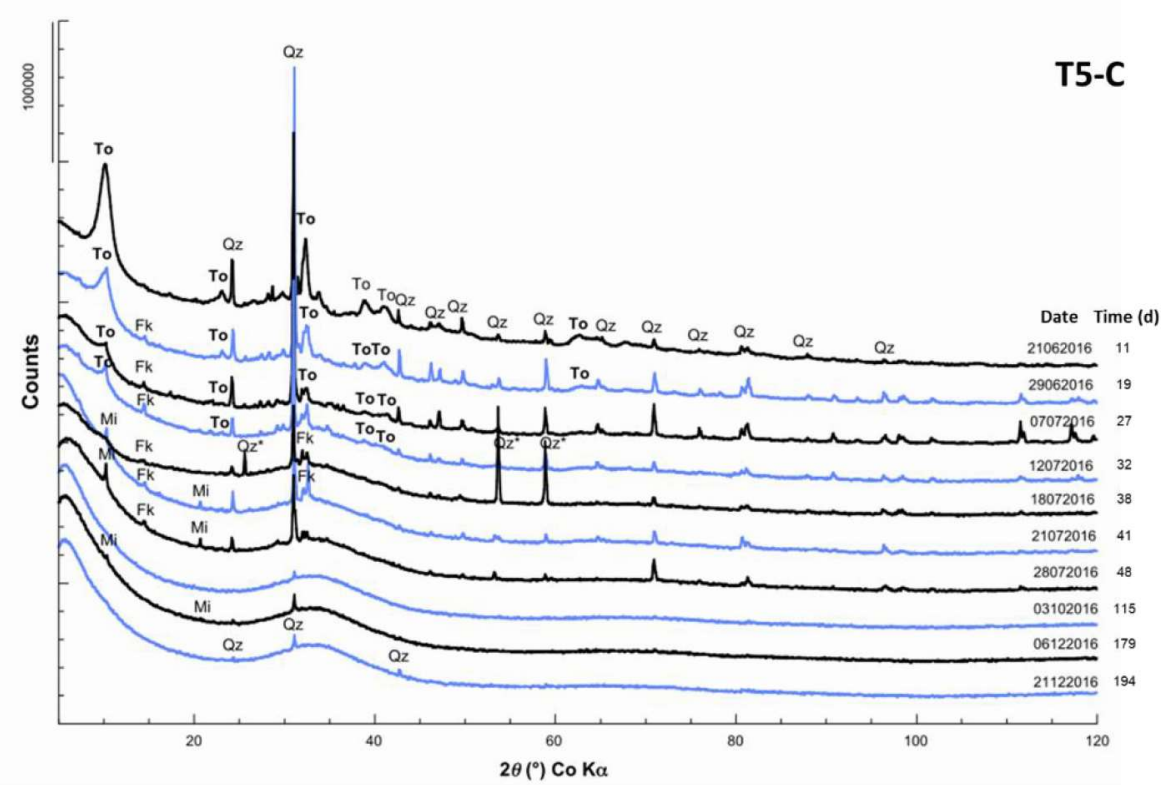

Figure 6. Evolution of X-ray diffractograms on the biogenic precipitate in tray T5-C during the monitoring period. $\mathrm{Qz}=$ quartz, To = tooeleite, $\mathrm{Fk}=$ potassium feldspar, $\mathrm{Mi}$ $=$ micas. 

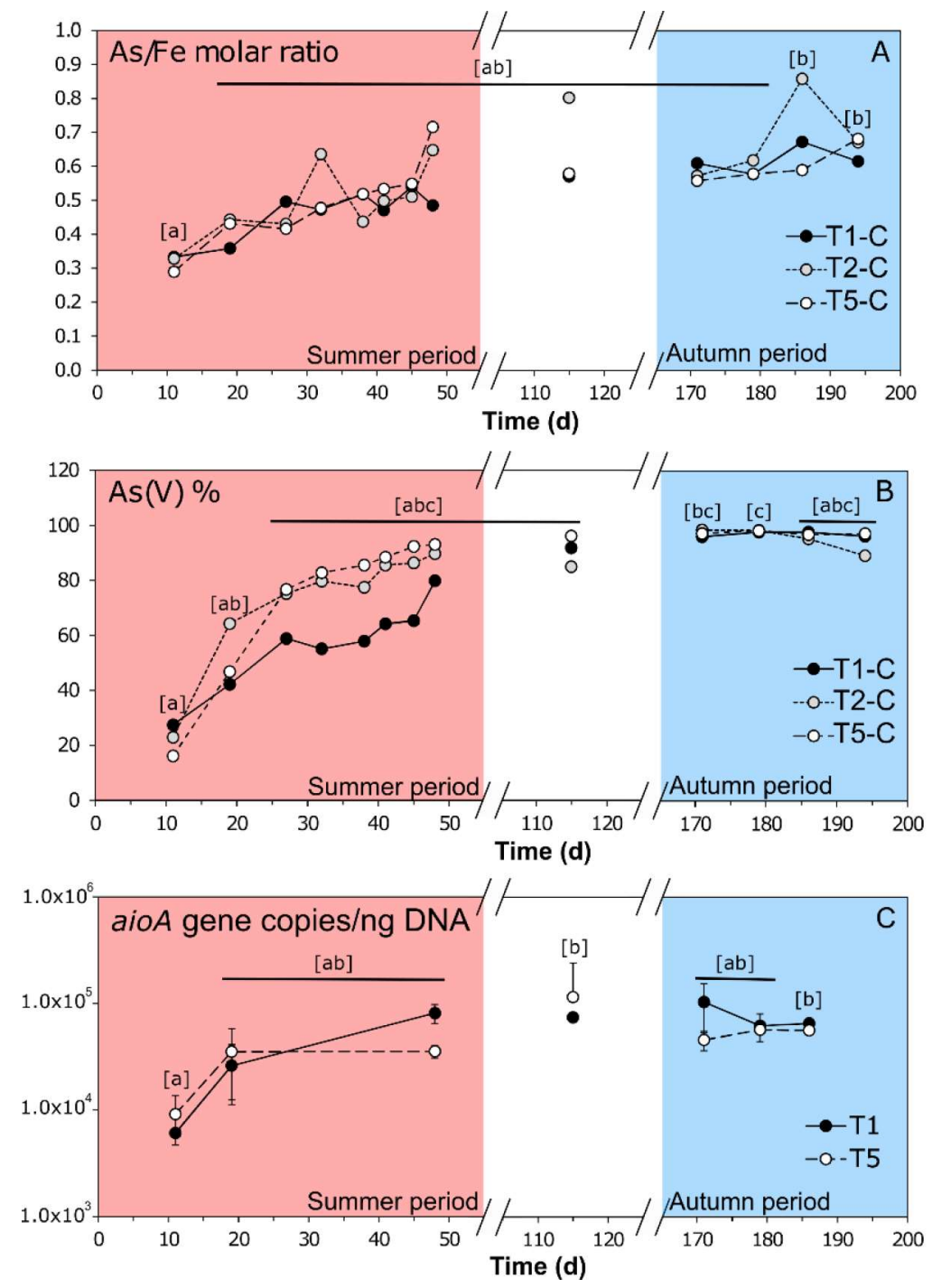

Figure 7. Evolution of As/Fe molar ratio (A) and $\mathrm{As}(\mathrm{V})$ percentage (B) in the biogenic precipitate from trays $\mathrm{T} 1-\mathrm{C}, \mathrm{T} 2-\mathrm{C}$, and $\mathrm{T} 5-\mathrm{C}$ during the monitoring period. Evolution of number of aioA gene copies/ng of DNA for trays T1 and T5 (A, B, and C section samples) during the same time (C). Different letters in brackets indicate statistically significant differences according to Friedman ( $p$-value $<0.05$ ) and Nemenyi multiple pairwise comparisons tests. 
Table 1. Comparison with other field trials exploiting biological or chemical Fe precipitation and As removal from AMD water in passive treatment devices

\begin{tabular}{|c|c|c|c|c|c|c|c|c|c|c|c|c|c|}
\hline Reference & Site & Whole design & $\begin{array}{c}\text { System } \\
\text { evaluated }\end{array}$ & $\begin{array}{c}\text { Influent } \\
\mathrm{pH}\end{array}$ & $\begin{array}{c}\text { Influent } \\
\text { As } \\
\left(\mathrm{mg} \mathrm{L}^{-1}\right)\end{array}$ & $\begin{array}{c}\text { Influent } \\
\mathrm{Fe} \\
\left(\mathrm{mg} \mathrm{L}^{-1}\right)\end{array}$ & $\begin{array}{c}\text { As } \\
\text { removal } \\
\%\end{array}$ & $\begin{array}{c}\mathrm{Fe} \\
\text { removal } \\
\%\end{array}$ & $\begin{array}{c}\text { As } \\
\text { removal } \\
\text { rate } \\
\left(\mathrm{g} \mathrm{m}^{-2} \mathrm{~d}^{-1}\right)\end{array}$ & $\begin{array}{c}\mathrm{Fe} \\
\text { removal } \\
\text { rate } \\
\left(\mathrm{g} \mathrm{m}^{-2} \mathrm{~d}^{-1}\right)\end{array}$ & $\begin{array}{c}\text { HRT } \\
\text { (h) }\end{array}$ & Mineralogy & $\begin{array}{c}\text { As/Fe molar } \\
\text { ratio or As } \\
\text { concentration in } \\
\text { the solid phase }\end{array}$ \\
\hline \multicolumn{14}{|l|}{ Biological treatments } \\
\hline This study & $\begin{array}{l}\text { Carnoulés mine } \\
\text { (France) }\end{array}$ & $\begin{array}{l}5 \text { acrobic ponds stacked on top } \\
\text { of each other connected by } \\
\text { cascades }\end{array}$ & Whole system & $2.6-3.5$ & $85-150$ & $790-1320$ & $3-97$ & $<0-11$ & $2-13$ & $<0-54$ & $2.3-50$ & $\begin{array}{l}\text { Toocleite, } \\
\text { Amophhous } \\
\text { ferric arsenate }\end{array}$ & $0.29 \_0.86$ \\
\hline Elbaz-Poulichet et aL (2006) & $\begin{array}{l}\text { Carnoulès mine } \\
\text { (France) }\end{array}$ & $\begin{array}{l}\text { Acrobic pond ( } 3 \text { different } \\
\text { configurations a) with ridges, } \\
\text { b) shallow pond, c) with } \\
\text { cascades) + +ecantation pond } \\
\text { (DP) + anacrobic wetland }\end{array}$ & Aerobic ponds & $2.5-4.5$ & $50-250$ & $800-1200$ & $11-20$ & n.s. & $5-10$ & n.s. & $0.5-3$ & n.s. & n.s. \\
\hline Macias et al. (2012) & $\begin{array}{l}\text { Monte Romero mine } \\
\text { (Spain) }\end{array}$ & $\begin{array}{l}\text { Natural iron oxidizing lagoon } \\
\text { (NFOL) + dispersed alkaline } \\
\text { substrate (DAS) + } 2 \text { DP joined } \\
\text { by cascades + DAS }\end{array}$ & NFOL & -3 & $0.1-1$ & $\begin{array}{c}275(99 \%) \\
\text { Fo(II)) }\end{array}$ & 80 & 38 & $0.1-1^{*}$ & $100^{\circ}$ & n.s. & $\begin{array}{l}\text { Sch, goe (friom } \\
\text { Phreceq } \\
\text { calculations) }\end{array}$ & $0.002^{*}$ \\
\hline Hamilton et al. (1999) & Wheal Jane mine (UK) & $\begin{array}{l}5 \text { acrobic wetlands }+ \text { anacrobic } \\
\text { pond }+ \text { rock filter }\end{array}$ & $\begin{array}{l}5 \text { acrobic } \\
\text { wetlands }\end{array}$ & -4 & 2.4 & -140 & $>99$ & 74 & n.s. & 1.2 & n.s. & n.s. & n.s. \\
\hline Whitehead et al. (2005) & Wheal Jane mine (UK) & $\begin{array}{l}5 \text { aerobic wetlands + anacrobic } \\
\text { pond + rock filter }\end{array}$ & $\begin{array}{l}5 \text { acrobic } \\
\text { wetlands }\end{array}$ & 3.8 & 2.7 & 144 & $>99^{*}$ & $75^{*}$ & n.s. & 5.8 (first unit) & n.s. & n.s. & $\begin{array}{l}<0.1 \% \text { As (first acrobic } \\
\text { cell) }\end{array}$ \\
\hline Kalin and Cactano Chaves (2003) & $\begin{array}{l}\text { Nova Lima mining } \\
\text { district (Brazil) }\end{array}$ & $\begin{array}{l}4 \text { oxidation-precipitation- } \\
\text { settling ponds }+3 \text { anacrobic } \\
\text { ponds }\end{array}$ & $\begin{array}{l}\text { first oxidation- } \\
\text { precipitation- } \\
\text { settling pond }\end{array}$ & $2-4$ & $<\mathrm{LD}$ & $20-300$ & n.s. & $\begin{array}{l}15-38 \text { ( } 4 \\
\text { acrobic } \\
\text { ponds) }\end{array}$ & -0.004 & -11 & 48 & n.s. & $\begin{array}{l}\sim 0.0004^{*} \text { ( }(4 \text { acrobic } \\
\text { ponds) }\end{array}$ \\
\hline \multicolumn{14}{|l|}{ Chemical treatments } \\
\hline Rörtting et al. (2008) & $\begin{array}{l}\text { Monte Romero mine } \\
\text { (Spain) }\end{array}$ & DAS +3 DP joined by cascades & DAS & $3.0-3.9$ & $0.1-1.5$ & $\begin{array}{l}290-357(95 \\
\% \text { Fe(II)) }\end{array}$ & 99 & $\begin{array}{l}48 \text { (whole } \\
\text { system) }\end{array}$ & $0.05-0.75^{*}$ & n.s. & 24 & $\begin{array}{l}\text { Sch, goe (0-3 } \\
\text { cm depth) }\end{array}$ & $\sim 0.002^{*}(0-3 \mathrm{~cm} \mathrm{depth})$ \\
\hline Caraballo et aL (2009) & $\begin{array}{l}\text { Monte Romero mine } \\
\text { (Spain) }\end{array}$ & $\begin{array}{l}\text { DAS }+2 \text { DP joined by } \\
\text { cascades }+ \text { DAS }+2 \text { DP joined } \\
\text { by cascades + DAS (MgO) }\end{array}$ & $1^{x}$ DAS & 3.08 & 0.3 & 358 & $>99$ & $\begin{array}{l}34\left(1^{*}\right. \\
\text { DAS+2 } \\
\text { DP) }\end{array}$ & n.s. & n.s. & $24 \mathrm{~h}$ & $\begin{array}{l}\text { Sch, goe (0-3 } \\
\text { cm depth) }\end{array}$ & n.s. \\
\hline Gusck et al. (1994) & Leviathan mine (USA) & $\begin{array}{l}\text { ALD, } 3 \text { aerobic pond, } \\
\text { anaerobic pond }\end{array}$ & Whole system & 4.5 & 0.1 & 340 & 90 & 99 & n.s. & n.s. & n.s. & n.s. & n.s. \\
\hline
\end{tabular}

"Calculated

n.s. = not specificd

$\mathrm{LD}=$ limit of detection
Sch $=$ schwertmannite, Goe $=$ goechite

\begin{tabular}{|c|c|c|c|c|c|c|c|c|c|c|c|c|c|}
\hline Reference & Site & Whole design & $\begin{array}{c}\text { System } \\
\text { evaluated }\end{array}$ & $\begin{array}{l}\text { Influent } \\
\mathrm{pH}\end{array}$ & $\begin{array}{l}\text { Influent } \\
\text { As } \\
\left(\mathrm{mg} \mathrm{L}^{-1}\right)\end{array}$ & $\begin{array}{c}\text { Influent } \\
\mathrm{Fe} \\
\left(\mathrm{mg} \mathrm{L}^{-1}\right)\end{array}$ & $\begin{array}{c}\text { As } \\
\text { removal } \\
\%\end{array}$ & $\begin{array}{c}\mathrm{Fe} \\
\text { removal } \\
\%\end{array}$ & $\begin{array}{c}\text { As } \\
\text { removal } \\
\text { rate } \\
\left(\mathrm{g} \mathrm{m}^{-2} \mathrm{~d}^{-1}\right)\end{array}$ & $\begin{array}{c}\mathrm{Fe} \\
\text { removal } \\
\text { rate } \\
\left(\mathrm{g} \mathrm{m}^{-2} \mathrm{~d}^{-1}\right) \\
\end{array}$ & $\begin{array}{l}\text { HRT } \\
\text { (h) }\end{array}$ & Mineralogy & $\begin{array}{c}\text { As/Fe molar } \\
\text { ratio or As } \\
\text { concentration in } \\
\text { the solid phase }\end{array}$ \\
\hline \multicolumn{14}{|l|}{ Biological treatments } \\
\hline This study & $\begin{array}{l}\text { Carnoulès mine } \\
\text { (France) }\end{array}$ & $\begin{array}{l}5 \text { aerobic ponds stacked on top } \\
\text { of each other connected by } \\
\text { cascades }\end{array}$ & Whole system & $2.6-3.5$ & $85-150$ & $790-1320$ & $3-97$ & $<0-11$ & $2-13$ & $<0-54$ & $2.3-50$ & $\begin{array}{l}\text { Toocleite, } \\
\text { Amophous } \\
\text { ferric arsenate }\end{array}$ & $0.29 \_0.86$ \\
\hline Elbaz-Poulichet et aL (2006) & $\begin{array}{l}\text { Carnoulès mine } \\
\text { (France) }\end{array}$ & $\begin{array}{l}\text { Acrobic pond ( } 3 \text { different } \\
\text { configurations a) with ridges, } \\
\text { b) shallow pond, c) with } \\
\text { cascades) + decantation pond } \\
\text { (DP) + anaerobic wetland }\end{array}$ & Aerobic ponds & $2.5-4.5$ & $50-250$ & $800-1200$ & $11-20$ & n.s. & $5-10$ & n.s. & $0.5-3$ & n.s. & n.s. \\
\hline Macias et al. (2012) & $\begin{array}{l}\text { Monte Romero mine } \\
\text { (Spain) }\end{array}$ & $\begin{array}{l}\text { Natural iron oxidizing lagoon } \\
\text { (NFOL) + dispersed alkaline } \\
\text { substrate (DAS) + } 2 \text { DP joined } \\
\text { by cascades + DAS }\end{array}$ & NFOL & -3 & $0.1-1$ & $\begin{array}{l}275(99 \%) \\
\text { Fo(II)) }\end{array}$ & 80 & 38 & $0.1-1^{*}$ & $100^{\circ}$ & n.s. & $\begin{array}{l}\text { Sch, goe (from } \\
\text { Phreegc } \\
\text { calculations) }\end{array}$ & $0.002^{*}$ \\
\hline Hamilton et al. (1999) & Wheal Jane mine (UK) & $\begin{array}{l}5 \text { acrobic wetlands }+ \text { anaerobic } \\
\text { pond }+ \text { rock filter }\end{array}$ & $\begin{array}{l}5 \text { acrobic } \\
\text { wetlands }\end{array}$ & -4 & 2.4 & -140 & $>99$ & 74 & n.s. & 1.2 & n.s. & n.s. & n.s. \\
\hline Whitehead et al. (2005) & Wheal Jane mine (UK) & $\begin{array}{l}5 \text { acrobic wetlands }+ \text { anaerobic } \\
\text { pond }+ \text { rock filter }\end{array}$ & $\begin{array}{l}5 \text { acrobic } \\
\text { wetlands }\end{array}$ & 3.8 & 2.7 & 144 & $>99^{*}$ & $75^{\circ}$ & n.s. & 5.8 (first unit) & n.s. & n.s. & $\begin{array}{l}<0.1 \% \text { As (first acrobic } \\
\text { cell) }\end{array}$ \\
\hline Kalin and Cactano Chaves (2003) & $\begin{array}{l}\text { Nova Lima mining } \\
\text { district (Brazil) }\end{array}$ & $\begin{array}{l}4 \text { oxidation-precipitation- } \\
\text { settling ponds }+3 \text { anaerobic } \\
\text { ponds }\end{array}$ & $\begin{array}{l}\text { first oxidation- } \\
\text { precipitation- } \\
\text { settling pond }\end{array}$ & $2-4$ & $<\mathrm{LD}$ & $20-300$ & n.s. & $\begin{array}{l}15 \_38 \text { (4 } \\
\text { acrobic } \\
\text { ponds) }\end{array}$ & -0.004 & -11 & 48 & n.s. & $\begin{array}{l}-0.0000^{*} \text { ( }(4 \text { acrobic } \\
\text { ponds) }\end{array}$ \\
\hline \multicolumn{14}{|l|}{ Chemical treatments } \\
\hline Rötting et al. (2008) & $\begin{array}{l}\text { Monte Romero mine } \\
\text { (Spain) }\end{array}$ & DAS +3 DP joined by cascades & DAS & $3.0-3.9$ & $0.1-1.5$ & $\begin{array}{l}290-357(95 \\
\% \text { Fe(II)) }\end{array}$ & 99 & $\begin{array}{l}48 \text { (whole } \\
\text { system) }\end{array}$ & $0.05-0.75^{*}$ & n.s. & 24 & $\begin{array}{l}\text { Sch, goe ( }(0-3 \\
\text { cm depth) }\end{array}$ & $\sim 0.002^{*}(0-3 \mathrm{~cm}$ depth $)$ \\
\hline Carakallo et aL (2009) & $\begin{array}{l}\text { Monte Romero mine } \\
\text { (Spain) }\end{array}$ & $\begin{array}{l}\text { DAS }+2 \text { DP joined by } \\
\text { cascades + DAS }+2 \text { DP joined } \\
\text { by cascades + DAS (MgO) }\end{array}$ & $1^{x}$ DAS & 3.08 & 0.3 & 358 & $>99$ & $\begin{array}{l}34\left(1^{*}\right. \\
\text { DAS+2 } \\
\text { DP) }\end{array}$ & n.s. & n.s. & $24 \mathrm{~h}$ & $\begin{array}{l}\text { Sch, goe (0-3 } \\
\text { cm depth) }\end{array}$ & n.s. \\
\hline Gusck et al. (1994) & Leviathan mine (USA) & $\begin{array}{l}\text { ALD, } 3 \text { aerobic pond, } \\
\text { anacrobic pond }\end{array}$ & Whole system & 4.5 & 0.1 & 340 & 90 & 99 & n.s. & n.s. & n.s. & n.s. & n.s. \\
\hline 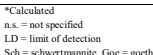 & & & & & & & & & & & & & \\
\hline
\end{tabular}

\begin{tabular}{|c|c|c|c|c|c|c|c|c|c|c|c|c|c|}
\hline Reference & Site & Whole design & $\begin{array}{c}\text { System } \\
\text { evaluated }\end{array}$ & $\begin{array}{c}\text { Influent } \\
\mathrm{pH}\end{array}$ & $\begin{array}{c}\text { Influent } \\
\text { As } \\
\left(\mathrm{mg} \mathrm{L}^{-1}\right)\end{array}$ & $\begin{array}{c}\text { Influent } \\
\text { Fe } \\
\left(\mathrm{mg} \mathrm{L}^{-1}\right)\end{array}$ & $\begin{array}{c}\text { As } \\
\text { removal } \\
\%\end{array}$ & $\begin{array}{c}\mathrm{Fe} \\
\text { removal } \\
\%\end{array}$ & $\begin{array}{c}\text { As } \\
\text { removal } \\
\text { rate } \\
\left(\mathrm{g} \mathrm{m}^{-2} \mathrm{~d}^{-1}\right)\end{array}$ & $\begin{array}{c}\mathrm{Fe} \\
\text { removal } \\
\text { rate } \\
\left(\mathrm{g} \mathrm{m}^{-2} \mathrm{~d}^{-1}\right)\end{array}$ & $\begin{array}{c}\text { HRT } \\
\text { (h) }\end{array}$ & Mineralogy & $\begin{array}{c}\text { As/Fe molar } \\
\text { ratio or As } \\
\text { concentration in } \\
\text { the solid phase }\end{array}$ \\
\hline \multicolumn{14}{|l|}{ Biological treatments } \\
\hline This study & $\begin{array}{l}\text { Carnoulés mine } \\
\text { (France) }\end{array}$ & $\begin{array}{l}5 \text { acrobic ponds stacked on top } \\
\text { of each other connected by } \\
\text { cascades }\end{array}$ & Whole system & $2.6-3.5$ & $85-150$ & $790-1320$ & $3-97$ & $<0-11$ & $2-13$ & $<0-54$ & $2.3-50$ & $\begin{array}{l}\text { Toocleite, } \\
\text { Amophhous } \\
\text { ferric arsenate }\end{array}$ & $0.29 \_0.86$ \\
\hline Elbaz-Poulichet et al (2006) & $\begin{array}{l}\text { Carnoulès mine } \\
\text { (France) }\end{array}$ & $\begin{array}{l}\text { Acrobic pond ( } 3 \text { different } \\
\text { configurations a) with ridges, } \\
\text { b) shallow pond, c) with } \\
\text { cascades) + decantation pond } \\
\text { (DP) + anacrobic wetland }\end{array}$ & Aerobic ponds & $2.5-4.5$ & $50-250$ & $800-1200$ & $11-20$ & n.s. & $5-10$ & n.s. & $0.5-3$ & n.s. & n.s. \\
\hline Macias et al. (2012) & $\begin{array}{l}\text { Monte Romero mine } \\
\text { (Spain) }\end{array}$ & $\begin{array}{l}\text { Natural iron oxidizing lagoon } \\
\text { (NFoL)+ dispersed alkaline } \\
\text { substrate (DAS) +2 DP joinod } \\
\text { by cascades + DAS }\end{array}$ & NFOL & -3 & $0.1-1$ & $\begin{array}{l}275(99 \% \\
\text { Fo(II)) }\end{array}$ & 80 & 38 & $0.1-1^{*}$ & $100^{*}$ & n.s. & $\begin{array}{l}\text { Sch, goe (from } \\
\text { Phreegc } \\
\text { calculations) }\end{array}$ & $0.002^{*}$ \\
\hline Hamilton et al. (1999) & Wheal Jane mine (UK) & $\begin{array}{l}5 \text { acrobic wetlands }+ \text { anaerobic } \\
\text { pond }+ \text { rock filter }\end{array}$ & $\begin{array}{l}5 \text { acrobic } \\
\text { wetlands }\end{array}$ & -4 & 2.4 & -140 & $>99$ & 74 & n.s. & 1.2 & n.s. & n.s. & n.s. \\
\hline Whitehead et al. (2005) & Wheal Jane mine (UK) & $\begin{array}{l}5 \text { aerobic wetlands + anacrobic } \\
\text { pond + rock filter }\end{array}$ & $\begin{array}{l}5 \text { acrobic } \\
\text { wetlands }\end{array}$ & 3.8 & 2.7 & 144 & $>99 *$ & $75^{*}$ & n.s. & 5.8 (first unit) & n.s. & n.s. & $\begin{array}{l}<0.1 \% \text { As (first acrobic } \\
\text { cell) }\end{array}$ \\
\hline Kalin and Cactano Chaves (2003) & $\begin{array}{l}\text { Nova Lima mining } \\
\text { district (Brazil) }\end{array}$ & $\begin{array}{l}4 \text { oxidation-precipitation- } \\
\text { settling ponds }+3 \text { anacrobic } \\
\text { ponds }\end{array}$ & $\begin{array}{l}\text { first oxidation- } \\
\text { precipitation- } \\
\text { settling pond }\end{array}$ & $2-4$ & $<\mathrm{LD}$ & $20-300$ & n.s. & $\begin{array}{l}15-38 \text { ( } 4 \\
\text { acrobic } \\
\text { ponds) }\end{array}$ & -0.004 & -11 & 48 & n.s. & $\begin{array}{c}-0.000 \mathcal{A}^{*}(4 \text { acrobic } \\
\text { ponds) }\end{array}$ \\
\hline \multicolumn{14}{|l|}{ Chemical treatments } \\
\hline Rörtting et al. (2008) & $\begin{array}{l}\text { Monte Romero mine } \\
\text { (Spain) }\end{array}$ & DAS +3 DP joined by cascades & DAS & $3.0-3.9$ & $0.1-1.5$ & $\begin{array}{l}290-357(95 \\
\% \text { Fe(II)) }\end{array}$ & 99 & $\begin{array}{l}48 \text { (whole } \\
\text { system) }\end{array}$ & $0.05-0.75^{*}$ & n.s. & 24 & $\begin{array}{l}\text { Sch, goe (0-3 } \\
\text { cm depth) }\end{array}$ & $-0.002^{*}(0-3 \mathrm{~cm} \mathrm{depth})$ \\
\hline Caraballo et aL (2009) & $\begin{array}{l}\text { Monte Romero mine } \\
\text { (Spain) }\end{array}$ & $\begin{array}{l}\mathrm{DAS}+2 \mathrm{DP} \text { joined by } \\
\text { cascades }+\mathrm{DAS}+2 \mathrm{DP} \text { joined } \\
\text { by cascades }+\mathrm{DAS}(\mathrm{MgO})\end{array}$ & $\mathrm{I}^{4} \mathrm{DAS}$ & 3.08 & 0.3 & 358 & $>99$ & $\begin{array}{c}34\left(1^{*}\right. \\
\text { DAS+2 } \\
\text { DP) }\end{array}$ & n.s. & n.s. & $24 \mathrm{~h}$ & $\begin{array}{l}\text { Sch, goe (0-3 } \\
\text { cm depth) }\end{array}$ & n.s. \\
\hline Gusck et al. (1994) & Leviathan mine (USA) & $\begin{array}{l}\text { ALD, } 3 \text { aerobic pond, } \\
\text { anaerobic pond }\end{array}$ & Whole system & 4.5 & 0.1 & 340 & 90 & 99 & n.s. & n.s. & n.s. & n.s. & n.s. \\
\hline
\end{tabular}

(1)

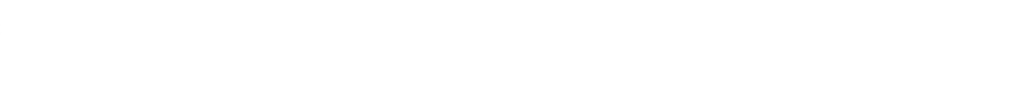

(2)

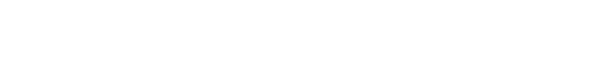

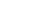

